\title{
RHEUMATOID ARTHRITIS (R.A.) FACTOR IN NEAR RELATIVES OF SERO-POSITIVE AND SERO-NEGATIVE PATIENTS WITH RHEUMATOID ARTHRITIS
}

BY

\author{
J. J. DE BLÉCOURT, F. WESTENDORP BOERMA, AND E. O. VORENKAMP \\ From the Rheumatism Unit, Department of Internal Medicine, and the Bacterial-Serological Laboratory, \\ University Hospital, Groningen
}

In a previous publication (de Blécourt, Polman, and de Blécourt-Meindersma, 1961), we drew attention to the familial occurrence of rheumatoid arthritis and ankylosing spondylitis, each of which shows a special hereditary factor, but we did not report on the presence or absence of the so-called rheumatic factor in probands and members of the family.

The "epidemiology" of various rheumatic conditions, including rheumatoid arthritis, has been the subject of several international conferences," and it has been stated by various workers (for instance, Lawrence and Ball, 1958; Bremner, Alexander, and Duthie, 1959; Ziff, Schmid, Lewis, and Tanner, 1958; Ziff, 1961; Karten, DiTata, McEwan, and Tanner, 1962) that more persons with rheumatoid arthritis and/or positive serological reactions (showing the presence of the so-called rheumatoid factor) are found among the near relatives of sero-positive rheumatoid arthritics than among those of sero-negative arthritics.

In near relatives of sero-positive rheumatoid arthritics, Lawrence and Ball (1958) found 20 per cent. with a positive Waaler-Rose test (as modified by Ball, 1950), and in a "mixed" group of seropositive and sero-negative probands they found 13 per cent. sero-positive relatives. In a group of normal controls, there were only 3 per cent. seropositive persons (so-called false positives).

Ziff and others (1958) found 16 per cent. seropositive near relatives in a group of sero-positive rheumatoid arthritics, and 1 per cent. false positives in a control group.

Bremner and others (1959) found no significant difference in results of the Waaler-Rose test in the

* First International Conference on Population Studies in Rheumatoid Arthritis, 1957 (Transactions, ed. J. H. Kellgren, 1958); Second Conference, 1962 (Transactions, in press); "Proceedings of the I.S.R.A. Symposium on the Social Aspects of Rheumatoid Arthritis" (1960). Elsevier, Amsterdam. relatives of sero-positive and sero-negative rheumatoid arthritics, but there was a slight tendency to find more sero-positive relatives in a group of seropositive probands.

Lawrence and Ball (1958) pointed out that the frequency of sero-positivity in relatives of seropositive probands was greater than in the normal population, whether clinical rheumatoid arthritis was present or not. In families of sero-negative patients with rheumatoid arthritis, clinical rheumatoid arthritis was more frequent, but sero-positivity was not. They concluded that possibly a seronegative form and a sero-positive form of rheumatoid arthritis were involved.

In the present study we have tried to make a small contribution to the question: Is this hereditary aetiological factor in rheumatoid arthritis restricted (or partly restricted) to sero-positive rheumatoid arthritis?

\section{Material}

We examined the near relatives (parents, siblings, and children aged 15 years and over) and also the spouses of 31 sero-positive and 31 sero-negative probands with definite or classical rheumatoid arthritis (A.R.A. criteria). The probands were regarded as sero-positive if both the Waaler-Rose test and the latex-fixation test (Singer and Plotz, 1956) were positive at dilutions $1: 32$ and $1: 160$ respectively. The probands were aged 45 to 60 years, each group included twelve males and nineteen females, and they all came from the "Rheumatism Unit" at Groningen.

In the sero-positive group of probands there were 226 near relatives alive, and in the sero-negative group 233. Of the 459 relatives, seventeen failed to co-operate, but 442 were examined, a completion rate of 96.5 per cent. All the probands were or had been married; 54 spouses were examined, two refused, and six were dead.

The serological tests were carried out and a physical examination was made by one of us (a rheumatologist) at the out-patient clinic or, in some cases, at the relative's home. 
The A.R.A. criteria were also used in reaching a diagnosis in the relatives, only definite or classical cases of rheumatoid arthritis being taken into account.

\section{Relatives}

\section{Results}

Sero-positive Probands.-Of the 226 relatives, five had sero-positive rheumatoid arthritis (Rose test + , latex test + ), five were healthy, but with Rose test and latex test + , and five were healthy but with Rose test + and latex test - .

Therefore $2 \cdot 2$ per cent. of the relatives ( 3 females and 2 males) had sero-positive rheumatoid arthritis, and 6.6 per cent. ( 8 females and 7 males) had one positive serological reaction.

Sero-negative Probands.--Of the 233 relatives, one had sero-negative rheumatoid arthritis (Rose test -, latex test -), one was healthy but sero-positive (Rose test + , latex text + ), and one was healthy but with Rose test + , and latex test - .

Therefore 0.45 per cent. of the relatives (one female) had sero-negative rheumatoid arthritis, and 0.9 per cent. (one male, one female) had one or two positive serological reactions.

\section{SPOUSES}

Of the 54 spouses examined, one had a positive latex-fixation test in the sero-positive group and one in the sero-negative group. None had rheumatoid arthritis.

It should be noted that the only relative in the sero-negative group with positive Rose and latexfixation tests was the healthy child of a proband and a healthy spouse in whom the latex-fixation test was positive.

The relatives of the sero-positive proband whose spouse had a positive latex-fixation test showed neither rheumatoid arthritis nor sero-positive tests.

\section{Discussion}

The incidence of clinical rheumatoid arthritis and sero-positivity in the relatives of sero-positive and sero-negative rheumatoid arthritics here reported is lower than that found by other workers. Perhaps the fact that only definite or classical rheumatoid arthritis in both probands and relatives was taken into account explains this difference.

In the present study the only significant difference was that between the 6.6 per cent. sero-positive reactions in the relatives of sero-positive probands and the 0.9 per cent. sero-positive reactions in the relatives of sero-negative probands $(P=0.05)$.
There is no significant difference between the results of the Waaler-Rose and latex-fixation tests 3 taken separately, nor in the incidence of clinicap rheumatoid arthritis in the relatives, but the numbers: involved are too small for a firm conclusion to bes drawn.

In our previous study we found rheumatoid arthritis in 2.35 per cent. of near relatives and in $\overline{\bar{p}}$. 0.8 per cent. of a control group, and these numbers were sufficient to conclude that a statisticallyb significant difference exists.

In the present study we found a similar result $\overrightarrow{0}$ $2 \cdot 2$ per cent. clinical rheumatoid arthritis in the relatives of sero-positive probands and 0.4 per cento clinical rheumatoid arthritis in the relatives of seros negative probands. This seems to suggest thaf sero-positive rheumatoid arthritis has a slight hereditary trend and that the sero-negative form $\tilde{\omega}_{\omega}^{+}$ has not. This agrees with Lawrence's view that sero-positive rheumatoid arthritis shows a distinct hereditary factor; but not with his view that the relatives even of sero-negative rheumatoid arthritics are more likely to have rheumatoid arthritis than the general population. However, our figures are rathere small for a definite conclusion to be drawn, and it is proposed to repeat this investigation on a larger scale and also in other parts of our country.

\section{Conclusion and Summary}

In 226 near relatives, aged 15 years and over, 31 probands with sero-positive rheumatoid arthritis, 2.2 per cent. of secondary sero-positive cases werEू found; 6.6 per cent. of the relatives were sero positive, but 4.4 per cent. of these were "false positives".

In 233 near relatives of 31 probands with sero negative rheumatoid arthritis, 0.45 per cent. of secondary sero-negative cases were found; 0.9 peto cent. of the relatives were sero-positive.

There exists a statistically significant differences $(P=0.05)$ between the percentages of sero-positive and sero-negative relatives of the probands in the sero-positive and sero-negative groups.

The figures given are too small for a firm con음 clusion to be drawn, but it seems that the sero $\rightarrow$ positive form of rheumatoid arthritis has a (slight) hereditary trend and that the sero-negative form has not.

REFERENCES
Blécourt, J. J. de, Polman, A., and Blécourt-Meindersma
T. de (1961). Ann. rheum. Dis., 20, 215. Bremner, J. M., Alexander, W. R. M., and Duthieo J. J. R. (1959). Ibid., 18, 279.

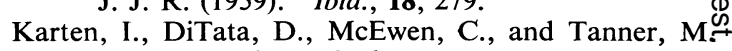
(1962). Arthr. and Rheum., 5, 131. 
Kellgren, J. H. (ed.) (1958). "Transactions of the First International Conference on Population Studies in Rheumatoid Arthritis, 1957." Arthritis and Rheumatism Foundation, New York.

Lawrence, J. S., and Ball, J. (1958). Ann. rheum. Dis., $17,160$.

Singer, J. M., and Plotz, C. M. (1956). Amer. J. Med., 21, 888.

Ziff, M. (1961). Ibid., 30, 1.

, Schmid, F. R., Lewis, A. J., and Tanner, M. (1958). Arthr. and Rheum., 1, 392.

Le facteur arthrite rhumatismale (R.A.) chez de proches parents des malades, séro-positifs et séro-négatifs, atteints d'arthrite rhumatismale

\section{RÉSUMÉ}

Parmi 226 proches parents, âgés de 15 ans ou plus, de 31 sujets atteints d'arthrite rhumatismale séro-positive, on trouva $2,2 \%$ des cas séro-positifs secondaires. Pour commencer le pourcentage des parents séro-positifs fut $6,6 \%$, mais $4,4 \%$ d'entre eux furent de "faux positifs".

Parmi 233 proches parents de 31 sujets atteints d'arthrite rhumatismale séro-négative, on trouva $0,45 \%$ des cas séro-négatifs secondaires; $0,9 \%$ des parents furent séro-positifs.

Il $\mathrm{y}$ a une différence statistiquement significative $(P=0,05)$ entre les pourcentages des parents séro- positifs et séro-négatifs des sujets dans les groupes séropositifs et séro-négatifs.

Ces chiffres sont trop petits pour arriver à une conclusion ferme, mais il semble que la forme séro-positive de l'arthrite rhumatismale a une (légère) tendance héréditaire et que la forme séro-négative n'en a pas.

El factor artritis reumatoide (R.A.) en parientes cercanos de sero-positivos y sero-negativos enfermos con artritis reumatoide

\section{SUMARIO}

Entre 226 parientes cercanos, de 15 y más años de edad, de 31 sujetos con artritis reumatoide sero-positiva, se encontró un 2,2\% de casos sero-positivos secundarios. Al principio un 6,6\% de los parientes fué positivo, pero en un $4,4 \%$ de ellos hubo "falsa positividad".

Entre 233 parientes cercanos de 31 sujetos con artritis reumatoide sero-negativa se encontró un $0,45 \%$ de casos sero-negativos secundarios; en un $0,9 \%$ los parientes fueron sero-positivos.

Hay una diferencia estadisticamente significativa $(P=0,05)$ entre la proporción de los parientes seropositivos y sero-negativos de los sujetos en los grupos sero-positivos y sero-negativos.

Estas cifras son demasiado pequeñas para llegar a una conclusión firme, pero parece que la forma sero-positiva de la artritis reumatoide tiene una (ligera) tendencia hereditaria mientras que la forma sero-negativa no la tiene. 